\title{
Fecal Contamination of Drinking Water Was Associated with Diarrheal Pathogen Carriage among Children Younger than 5 Years in Three Peruvian Rural Communities
}

\author{
Steev Loyola, ${ }^{1,2 \star}$ Juan F. Sanchez, ${ }^{2,3}$ Edson Maguiña, ${ }^{2}$ Enrique Canal, ${ }^{2}$ Rosa Castillo, ${ }^{2}$ Manuela Bernal, ${ }^{2}$ Yocelinda Meza, ${ }^{2}$ \\ Drake H. Tilley, ${ }^{2}$ William E. Oswald, ${ }^{4}$ Kristen Heitzinger, ${ }^{5}$ Andres G. Lescano, ${ }^{2,3}$ and Claudio A. Rocha ${ }^{2}$ \\ ${ }^{1}$ School of Medicine, Universidad Peruana Cayetano Heredia, Lima, Peru; ${ }^{2}$ U.S. Naval Medical Research Unit No. 6, Lima, Peru; ${ }^{3}$ Emerge, \\ Emerging Diseases and Climate Change Research Unit, School of Public Health and Administration, Universidad Peruana Cayetano Heredia, Lima, \\ Peru; ${ }^{4}$ Faculty of Infectious and Tropical Diseases, London School of Hygiene \& Tropical Medicine, London, United Kingdom; ${ }^{5}$ Asociacion
} Benefica PRISMA, Lima, Peru

\begin{abstract}
Drinking water contamination is a frequent problem in developing countries and could be associated with bacterial pathogen carriage in feces. We evaluated the association between the risk of drinking water and bacterial carrier status in children younger than 5 years in a cross-sectional study conducted in 199 households from three Peruvian rural communities. Fecal samples from children were screened for pathogenic Aeromonas, Campylobacter, and Vibrio species, as well as for Enterobacteriaceae, including pathogenic Escherichia coli. The drinking water risk was determined using $E$. coli as an indicator of contamination. Nineteen $(9.5 \%)$ children were colonized with pathogens and classified as carriers, all without diarrhea symptoms. Of 199 drinking water samples, 38 (19.1\%) were classified as very high risk because of high fecal contamination (> $100 \mathrm{E}$. coli/100 mL). Shared-use water sources, daily washing of containers, and washing using only water were associated with higher prevalence of bacterial carriage, whereas there was no association between households reporting boiling and chlorination of water and carrier status. The prevalence of carriage in children exposed to very high-risk water was 2.82 (95\% Cl: 1.21-6.59) times the prevalence of those who consumed less contaminated water, adjusted by the water source and daily washing. Our results suggest that household drinking water plays an important role in the generation of carriers with diarrheal pathogens. Our findings also highlight the importance of interventions to ensure the safety of drinking water. Further studies are needed to validate the observed association and determine its significance with respect to diarrhea in the community.
\end{abstract}

\section{INTRODUCTION}

Fecal contamination of drinking water is a frequent problem in developing countries. ${ }^{1-7}$ Contaminated water represents a health threat as it can be a vehicle for pathogen transmission..$^{2,8-10}$ The association between contaminated drinking water and cholera is clear ${ }^{11,12}$ but does not apply equally to all diarrheal pathogens. ${ }^{12}$

The risk of diarrheal disease in children younger than 5 years can be reduced through interventions that promote access to clean water and sanitary facilities, hygiene practices, and water treatment. ${ }^{6,7,12,13}$ In rural areas of Peru, despite local efforts and interventions to promote clean and safe water, approximately $95 \%$ of children younger than 5 years are exposed to drinking water contaminated with fecal coliforms. ${ }^{14-17}$

Enterobacteriaceae, as well as Campylobacter and Aeromonas species are frequent causes of diarrhea that affect children younger than 5 years. ${ }^{18-20}$ The presence of pathogenic bacteria in children without diarrheal symptoms has been described previously, suggesting that a carrier state may exist among children exposed early to these pathogens. ${ }^{15,21}$ However, the literature about risk factors that may lead to this carrier state is limited, particularly in pediatric populations.

Several studies have shown that unsafe drinking water is associated with gastrointestinal infections. ${ }^{6,7,22}$ Researchers have also suggested that consumption of contaminated water may be associated with a carrier state of pathogenic bacteria. ${ }^{23,24}$ It is possible that children exposed to frequent consumption of contaminated drinking water will develop an immunity and

\footnotetext{
*Address correspondence to Steev Loyola, School of Medicine, Universidad Peruana Cayetano Heredia, Honorio Delgado 430 Av., San Martín de Porres, Lima 15102, Peru. E-mails: steev.loyola@ gmail.com or steev.loyola@upch.pe
}

tolerance to frequently consumed bacterial pathogens that may lead to asymptomatic carriage. Therefore, we aimed to evaluate the association between contaminated household drinking water and the carriage of pathogenic bacteria in children younger than 5 years.

\section{MATERIALS AND METHODS}

Study population and participants. The study was conducted in Independencia (13 $\left.13^{\circ} 41^{\prime} 34.5^{\prime \prime S} 76^{\circ} 01^{\prime} 32.9^{\prime \prime} \mathrm{W}\right)$, Bernales $\left(13^{\circ} 44^{\prime} 42.3^{\prime \prime S} 75^{\circ} 57^{\prime} 54.2^{\prime \prime} \mathrm{W}\right)$, and Huancano (13'36'05.1"S $75^{\circ} 37^{\prime} 11.0^{\prime \prime} \mathrm{W}$ ), all located in a rural area of the Pisco Province of the Peruvian southern coast. In August 2007, an earthquake occurred in Pisco affecting $70 \%$ of its homes and the water distribution system and sewage systems of the communities included in this study. ${ }^{25}$ Three years later, these three communities still had intermittent and limited access to chlorinated water through domestic pipes for some hours during the day. ${ }^{26}$

Study design and data collection. A cross-sectional study was conducted in 199 households during August 2010. Researchers from the United States Naval Medical Research Unit No. 6 (NAMRU-6) in collaboration with Peace Corps Volunteers, public health authorities, community leaders, and members of the "Vaso de Leche" program of Independencia, Bernales, and Huancano identified 450 households distributed among the three communities where at least one child younger than 5 years lived (referred to as child henceforth). A total of 199 (44.2\%) households were randomly selected in a sampling with proportional probability to the population size of each community. One child was enrolled in each household, selected randomly from among the children in each household with more than one eligible child. Assessments in each house involved 1) a survey of sociodemographic characteristics, hygiene practices, and water treatment practices; 2) a stool 
sample from the enrolled child; and 3) a sample of the household drinking water.

Survey. The survey questionnaire was designed using questions from the Peruvian Demographic Health Survey ${ }^{27}$ and was evaluated in a pilot study and validated in a neighboring community with similar characteristics to the communities included in this study. The survey consisted of 45 questions which took approximately 30 minutes to complete. Field workers were trained and evaluated in the survey administration. After verbal informed consent was obtained, the survey was administered to either the child's mother or to a caregiver if the mother was absent.

Stool samples. After the survey administration, field workers provided instructions to the mother/caregiver for collecting stool sample from the child. Briefly, the child defecated into a clean and sterile container provided by the field workers or in a diaper if collection in the container was not possible. Then, the mother/caregiver stored the feces in a sterile screw-top container for delivery to the field worker. The stool sample was retrieved by the field workers within 24 hours from sample collection. Once the sample was received, the field worker selected a representative part of the sample $(\sim 2.0 \mathrm{~g})$ and inoculated it into Cary-Blair transport medium. Stool samples were then transported daily at $4^{\circ} \mathrm{C}$ from each community to the NAMRU-6 laboratory in Lima, Peru.

Drinking water samples. Field workers were trained and evaluated on the drinking water sample collection procedures. On the day of the survey, the field worker asked the mother/ caregiver to identify the principal drinking water container used for the child's water consumption. If there were multiple containers, then one would be randomly selected. The field worker would then collect $100 \mathrm{~mL}$ of water from the selected container in a sterile $100-\mathrm{mL}$ bottle to be transported that day at $4^{\circ} \mathrm{C}$ to the laboratory at NAMRU-6.

Laboratory methods. Stool samples. Stool samples were tested for the presence of pathogenic Enterobacteriaceae and species of Aeromonas, Campylobacter, and Vibrio using MacConkey, Hektoen, xylose lysine deoxycholate, Campy, and thiosulfate-citrate-bile salts-sucrose plates. Culture-based methods are still considered as the gold standard for detection of pathogenic bacteria. In addition, real-time polymerase chain reaction assays $(100.0 \%$ specific and $99.0 \%$ sensitive) were performed to detect six classes of pathogenic Escherichia coli. ${ }^{28}$

Drinking water samples. The presence of $E$. coli was tested in drinking water samples and quantified using the most probable number in $100 \mathrm{~mL}$ using the Quanti-Tray 200, Colilert kit (Idexx Laboratories, Westbrook, ME), following the manufacturer's instructions.

Ethical approvals. The study was approved by NAMRU6's Institutional Review Board (NMRCD.2009.0006). The mothers and caregivers agreed to participate through informed consent and also approved the child's enrollment. This study was also approved by the Universidad Peruana Cayetano Heredia as the Master's thesis of the lead author (SIDISI: 66909).

Measures and analysis. Outcome variable. The carriage of pathogenic bacteria was defined dichotomously (yes/no). Children with at least one type of pathogenic bacteria detected in the stool sample were classified as carriers.

Exposure of interest. Drinking water samples with $>100$ E. coli/100 $\mathrm{mL}$ were classified as "very high risk" following the
WHO's health risk categories. ${ }^{29}$ Drinking water with no detectable E. coli or with 1-100 E. coli/100 mL was classified as "not very high risk." "29,30

Main covariate. The other covariates were grouped into 1) child demographics (gender and age) and malnutrition (global, chronic, and acute malnutrition), 2) socioeconomic status and water source, 3) hygiene practices (daily washing of the drinking water storage container and cleaning supplies), and 4) water treatment methods (boiling and chlorination). Global, chronic, and acute malnutrition were defined dichotomously if a child's indices of weight-age, height-age, and weightheight were 2 SDs below the reference population's median, respectively. ${ }^{31}$ A socioeconomic status index was estimated using a principal component analysis of assets and household characteristics. ${ }^{32,33}$ The water source type was dichotomized post hoc as "piped," if the house had access to water through a domestic pipe, or as a "shared-use" water source if the house only had access to a well or standpipe in the community. The frequency of washing the drinking water storage container was originally collected as an ordinal variable (number of times cleaned per week) but was analyzed as a dichotomous "daily wash" (yes/no) variable because of the high variability of its values.

Statistical analysis. The associations between carrier status and categorical variables were explored using Fisher's exact test. The ages of carriers and noncarriers were compared using the Mann-Whitney $U$ test. Crude prevalence ratio (PR) and adjusted PR (aPR) of carriage and their 95\% Cls were estimated using generalized linear models with a Poisson distribution, logarithmic function, and robust estimations of standard errors. Binomial distribution was not used because of the lack of convergence in multiple regression models. ${ }^{34-36}$ The variance inflation factor was evaluated to assess multicollinearity among covariates. The consistency of PR estimates for high-risk drinking water and carrier status was evaluated across all fitted multiple regression models. Data analysis was performed using Stata v14 (StataCorp, College Station, TX) considering a statistical significance of $P<0.05$.

\section{RESULTS}

Characteristics of the study population. A total of 199 children from Bernales (53.7\%), Huancano (16.1\%), and Independencia (30.2\%) were enrolled. The male:female ratio was 0.9 , and the median age was 2.4 years (Table 1 ). Pathogenic bacteria were detected in the stool of 19 children $(9.5 \%)$, who were classified as carriers. The carriers were detected in all three communities; seven from Bernales, one from Huancano, and 11 from Independencia. One child was carrying two pathogenic bacteria simultaneously and 18 were single carriers, resulting in a total of 20 bacterial isolates. Campylobacter jejuni was the most frequently isolated bacteria $(7 / 20$, $35.0 \%$ ), followed by Aeromonas caviae (6/20, 30.0\%), Campylobacter coli (3/20, 15.0\%), Aeromonas hydrophila (2/20, $10.0 \%)$, Aeromonas veroni (1/20, 5.0\%), and Shigella flexneri $(1 / 20,5.0 \%)$. No pathogenic $E$. coli were detected.

The mothers/caregivers of the carrier children reported that their child did not have diarrheal disease symptoms in the 3 days before enrollment. No children younger than 1.3 years were carriers of pathogenic bacteria (Table 1). We did not observe associations between gender, age, malnutrition, or socioeconomic status with carriage (Table 1). 
TABLE 1

Characteristics difference between noncarriers and carriers of enteric bacterial pathogens of enrolled children younger than 5 years

\begin{tabular}{|c|c|c|c|c|}
\hline & & Noncarrier $(n=180)$ & Carrier $(n=19)$ & \\
\hline & $\%(n / M)$ & $n(\%)$ & $n(\%)$ & $P$-value \\
\hline Gender & & & & 0.470 \\
\hline Female & $52.8(105 / 199)$ & 93 (88.6) & $12(11.4)$ & \\
\hline Male & $47.2(94 / 199)$ & $87(92.5)$ & $7(7.5)$ & \\
\hline Age (years) & $2.4(0.1-4.9)^{\star}$ & $2.3(0.1-4.9)^{\star}$ & $2.9(1.3-4.5)^{\star}$ & $0.172 \dagger$ \\
\hline$<1$ & $13.1(26 / 199)$ & $26(100.0)$ & $0(0.0)$ & 0.134 \\
\hline 1 to $<2$ & $26.1(52 / 199)$ & $45(86.5)$ & 7 (13.5) & \\
\hline$\geq 2$ to $<5$ & $60.8(121 / 199)$ & $109(90.1)$ & $12(9.9)$ & \\
\hline Global malnutrition & & & & 0.397 \\
\hline No & $95.5(190 / 199)$ & $171(90.0)$ & $19(10.0)$ & \\
\hline Yes & $4.5(9 / 199)$ & $9(100.0)$ & $0(0.0)$ & \\
\hline Chronic malnutrition & & & & 0.321 \\
\hline No & $83.9(167 / 199)$ & 149 (89.2) & $18(10.8)$ & \\
\hline Yes & $16.1(32 / 199)$ & 31 (96.9) & $1(3.1)$ & \\
\hline Acute malnutrition & & & & 1.000 \\
\hline No & $98.5(196 / 199)$ & $177(90.3)$ & $19(9.7)$ & \\
\hline Yes & $1.5(3 / 199)$ & $3(100.0)$ & $0(0.0)$ & \\
\hline Socioeconomic status & & & & 0.051 \\
\hline Lower & $34.6(69 / 199)$ & 62 (89.9) & 7 (10.1) & \\
\hline Half & $32.7(65 / 199)$ & 55 (84.6) & $10(15.4)$ & \\
\hline Upper & $32.7(65 / 199)$ & 63 (96.9) & $2(3.1)$ & \\
\hline Water source $\ddagger$ & & & & $<0.001$ \\
\hline Piped at home & $88.9(176 / 198)$ & 167 (94.9) & $9(5.1)$ & \\
\hline Shared & $11.1(22 / 198)$ & $12(54.6)$ & $10(45.4)$ & \\
\hline Daily washing of water storage container & & & & $<0.001$ \\
\hline No & $67.3(134 / 199)$ & $130(97.0)$ & $4(3.0)$ & \\
\hline Yes & $32.7(65 / 199)$ & 50 (76.9) & $15(23.1)$ & \\
\hline Cleaning supplies for washing $\ddagger$ & & & & 0.043 \\
\hline Water & $28.3(56 / 199)$ & $46(82.1)$ & $10(17.9)$ & \\
\hline Water + dishwashing & $38.4(76 / 199)$ & $70(92.1)$ & $6(7.9)$ & \\
\hline Water + bleach & $33.3(66 / 199)$ & 63 (95.5) & $3(4.5)$ & \\
\hline Boiling drinking water & & & & 0.480 \\
\hline No & $13.6(27 / 199)$ & $26(96.3)$ & $1(3.7)$ & \\
\hline Yes & $86.4(172 / 199)$ & $154(89.5)$ & $18(10.5)$ & \\
\hline Chlorinating drinking water & & & & 0.811 \\
\hline No & $53.8(107 / 199)$ & $96(89.7)$ & $11(10.3)$ & \\
\hline Yes & $46.2(92 / 199)$ & 84 (91.3) & $8(8.7)$ & \\
\hline Very high-risk water & & & & $<0.001$ \\
\hline No & $80.9(161 / 199)$ & $152(94.4)$ & $9(5.6)$ & \\
\hline Yes & $19.1(38 / 199)$ & 28 (73.7) & $10(26.3)$ & \\
\hline
\end{tabular}

p50 (mimum-maximumi

† Mann-Whitney U test

$\ddagger$ One missing value.

Water and hygiene practices. Of the 199 households, 177 $(88.9 \%)$ reported having a water connection inside the house used as the primary water source, whereas $22(11.1 \%)$ reported shared-use water sources because of lack of inhouse plumbing. Whether domestic pipes or shared water sources, all families reported storing water mainly for drinking and food preparation in plastic containers. Approximately one-third $(32.7 \%)$ of containers used to store drinking water were washed daily. Containers were most frequently washed with a combination of water and dishwashing soap (38.4\%). Most households also reported some form of treatment for drinking water, either by boiling $(86.4 \%)$ and/or chlorination (46.2\%).

We observed a significantly higher carriage frequency in those households that used shared water sources, reporting daily washing of containers, and reporting washing containers with only water (Table 1). Reports of water boiling and chlorination were not associated with carrier status (Tables 1 and 2).

In the multiple regression model, the water source type and daily container washing were independently associated with carrier status (Table 2). The carriage PR associated with using shared water sources compared with in-house pipes was 6.06 (95\% Cl: 2.71-13.58), after adjusting for daily washing. Also, the carriage prevalence in households reporting daily container washing was higher than for non-daily washing (PR: 5.48, 95\% Cl: 1.85-16.21), after adjustment by the water source. We did not observe associations between carriage and child characteristics or water treatment methods in multiple regression models adjusting for water source and daily washing.

A total of 38 (19.1\%) drinking water samples were classified as very high risk based on the level of $E$. coli contamination (Table 1). No statistical difference was observed in the $E$. coli load by water source type $(P=0.233$, Figure 1$)$. The carriage prevalence was higher in children exposed to very high-risk drinking water $(\mathrm{PR}=4.71,95 \% \mathrm{Cl}$ : 2.05-10.80, Table 2). Adjusting for the water source and daily container washing, the carriage prevalence was still higher in children exposed to the very high-risk drinking water (aPR: 2.82, 95\% Cl: 1.21-6.59, Table 2). The association between drinking water risk and carrier status was stable in consistency analyses despite multiple statistical adjustments (Table 3 ). 
TABLE 2

Prevalence ratios comparing children characteristics and water and hygiene practices between carriers and noncarriers of enteric bacterial pathogens

\begin{tabular}{|c|c|c|c|c|c|c|c|c|c|}
\hline & \multicolumn{3}{|c|}{ Unadjusted PR } & \multicolumn{3}{|c|}{ aPR $1^{*}$} & \multicolumn{3}{|c|}{ aPR $2 \dagger$} \\
\hline & PR & $95 \% \mathrm{Cl}$ & $P$-value & aPR & $95 \% \mathrm{Cl}$ & $P$-value & aPR & $95 \% \mathrm{Cl}$ & $P$-value \\
\hline \multicolumn{10}{|l|}{ Gender } \\
\hline Female & Ref. & & & Ref. & & & Ref. & & \\
\hline Male & 0.65 & $0.27-1.59$ & 0.347 & 0.62 & $0.27-1.38$ & 0.238 & 0.6 & $0.28-1.29$ & 0.188 \\
\hline \multicolumn{10}{|l|}{ Chronic malnutrition } \\
\hline No & Ref. & & & Ref. & & & Ref. & & \\
\hline Yes & 0.29 & $0.04-2.11$ & 0.221 & 0.27 & $0.04-1.62$ & 0.152 & 0.33 & $0.07-1.63$ & 0.174 \\
\hline \multicolumn{10}{|l|}{ Socioeconomic status } \\
\hline Lower & 0.66 & $0.27-1.63$ & 0.368 & 1.07 & $0.47-2.44$ & 0.875 & 1.08 & $0.51-2.25$ & 0.846 \\
\hline Half & Ref. & & & Ref. & & & Ref. & & \\
\hline Upper & 0.2 & $0.05-0.88$ & $<0.001$ & 0.25 & $0.06-1.04$ & 0.057 & 0.3 & $0.08-1.18$ & 0.085 \\
\hline \multicolumn{10}{|l|}{ Water source } \\
\hline Piped at home & Ref. & & & - & & & - & & \\
\hline Shared & 8.89 & $4.05-19.51$ & $<0.001$ & - & - & & - & - & - \\
\hline \multicolumn{10}{|c|}{ Daily washing of water storage container } \\
\hline No & Ref. & & & Ref. & & & - & & \\
\hline Yes & 7.73 & $2.66-22.43$ & $<0.001$ & 5.46 & $1.85-16.21$ & 0.002 & - & - & - \\
\hline \multicolumn{10}{|c|}{ Cleaning supplies for washing } \\
\hline Water & Ref. & & & Ref. & & & Ref. & & \\
\hline Water + dishwashing & 0.44 & $0.17-1.15$ & 0.094 & 0.43 & $0.13-1.48$ & 0.181 & 0.51 & $0.24-1.13$ & 0.099 \\
\hline Water + bleach & 0.03 & $0.07-0.88$ & 0.031 & 0.58 & $0.24-1.39$ & 0.218 & 0.58 & $0.15-2.16$ & 0.461 \\
\hline \multicolumn{10}{|l|}{ Boiling drinking water } \\
\hline No & Ref. & & & Ref. & & & Ref. & & \\
\hline Yes & 2.82 & $0.39-20.41$ & 0.303 & 2.35 & $0.42-13.05$ & 0.328 & 1.8 & $0.23-13.85$ & 0.572 \\
\hline \multicolumn{10}{|c|}{ Chlorinating drinking water } \\
\hline No & Ref. & & & Ref. & & & Ref. & & \\
\hline Yes & 0.85 & $0.35-2.02$ & 0.706 & 1.12 & $0.51-2.49$ & 0.772 & 1.22 & $0.48-2.55$ & 0.605 \\
\hline \multicolumn{10}{|l|}{ Very high-risk water } \\
\hline No & Ref. & & & Ref. & & & Ref. & & \\
\hline Yes & 4.71 & $2.05-10.80$ & $<0.001$ & 3.46 & $1.52-7.87$ & 0.003 & 2.82 & $1.21-6.59$ & 0.017 \\
\hline
\end{tabular}

\section{DISCUSSION}

We observed a strong association between very high-risk drinking water and carrier status with at least 2.6-fold higher prevalence of pathogenic bacteria carriage. The increase in

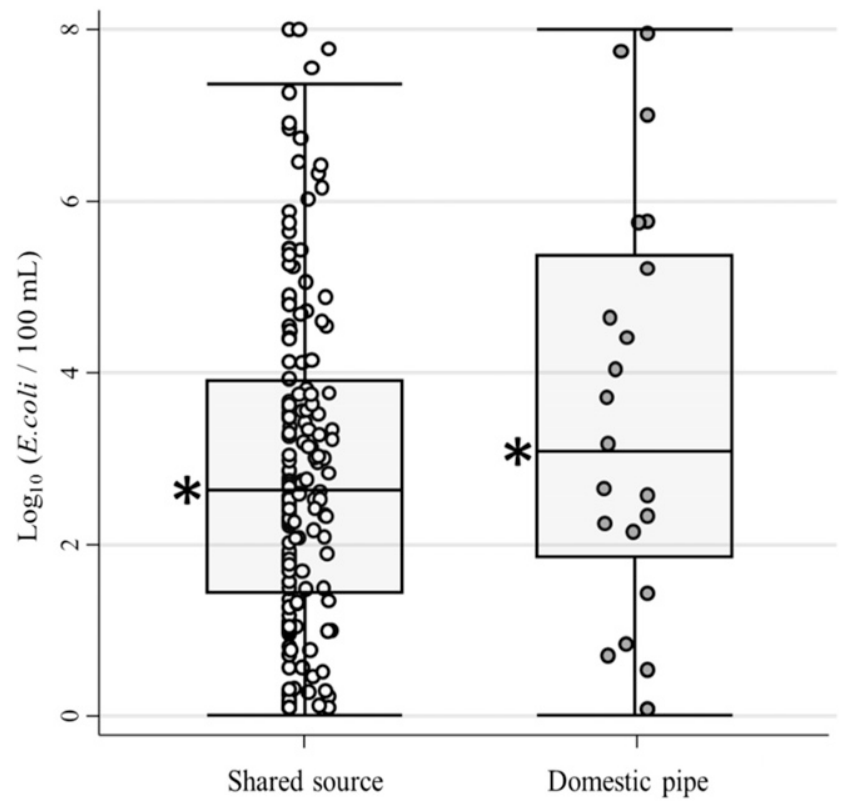

FIGURE 1. Load of Escherichia coli in drinking water by the type of water source. ${ }^{\star}$ Mann-Whitney $U$ test, $P$-value $=0.233$. carrier status was stable despite multiple statistical approaches looking for confounding factors and even reached a 4-fold increase in some scenarios. This association was previously described by Coleman et al. ${ }^{23}$ and suggested that exposure to very highly contaminated water may lead to the generation of bacterial pathogen carriers.

Nearly $10 \%$ of children sampled were positive for pathogenic bacteria, similar to results from a rural Peruvian community ${ }^{15}$ and other previous reports. ${ }^{19,20}$ It is very probable that the cases could have developed the disease in subsequent days, or the pathogen have been eliminated without causing disease, or that they served as reservoirs of pathogenic bacteria increasing the risk of contaminating their surroundings. This is especially significant in crowded settings such as day-care facilities and schools as caregivers are less attentive to good hygiene practices. ${ }^{37}$ As previously described, ${ }^{38}$ quantitative approaches to distinguish high- and low-level infections, serological evidence to estimate force of infection, and longitudinal studies to confirm the carrier status or symptomatic infections are needed to validate the association described here and also to better understand the burden of asymptomatic carriers in high-level infections.

The relatively high prevalence of positive cases for pathogenic bacteria with no symptoms of disease, its presence in multiple communities, and the fact that it is associated with multiple pathogens is associated with highly contaminated drinking water present in almost $20 \%$ of homes suggest that exposure to pathogenic bacteria is not a single, isolated event but rather a somewhat continuous situation at the community level. Interestingly, all 
TABLE 3

Consistency analysis of prevalence ratios for the carrier status considering children and sociodemographic characteristics, hygiene practices, and water treatment methods

\begin{tabular}{|c|c|c|c|c|}
\hline Very high-risk water & & aPR & $95 \% \mathrm{Cl}$ & $P$-value \\
\hline & No & Ref. & & \\
\hline Model A: Non-aPR considering the very high-risk water & Yes & 4.71 & $2.05-10.80$ & $<0.001$ \\
\hline $\begin{array}{l}\text { Model B: Model A adjusted with children characteristics } \\
\text { (gender and chronic malnutrition) }\end{array}$ & Yes & 4.40 & $1.94-9.98$ & $<0.001$ \\
\hline $\begin{array}{l}\text { Model C: Model B adjusted with sociodemographic } \\
\text { (socioeconomic status and water source) }\end{array}$ & Yes & 2.61 & $1.04-6.58$ & 0.041 \\
\hline $\begin{array}{l}\text { Model D: Model C adjusted with hygiene practices (daily } \\
\text { washing and cleaning supplies for washing the } \\
\text { storage container) }\end{array}$ & Yes & 4.00 & $1.06-15.18$ & 0.041 \\
\hline $\begin{array}{l}\text { Model E: Model D adjusted with water treatment } \\
\text { methods (drinking water boiling and chlorination) }\end{array}$ & Yes & 3.82 & $1.13-12.89$ & 0.031 \\
\hline
\end{tabular}

children carrying pathogenic bacteria in this population were older than 1 year. The mechanism and frequency of such tolerance to disease as well as to see if age and age-related characteristics are associated to carrier status and symptoms merit further research.

Water sources in low- and middle-income countries are frequently contaminated. ${ }^{2-4,17}$ Several studies suggest that increasing access to safe water could reduce the burden of diarrheal disease. . $^{3,5,7,39,40}$ Universal access to continuous water service through domestic pipes is generally seen as the first step to avoid the use of potentially unsafe water sources. However, piped water, and other improved water sources do not necessarily provide safe water. ${ }^{2,29,41,42}$ Our findings are consistent with other reports as we did not find significant differences in the microbial load of stored water in households with domestic pipes compared with those that access exclusively shared-use water sources. ${ }^{2,41}$ However, it is important to consider that the contamination of water samples collected in this study could reflect contamination that occurred anywhere from the water source to the point of consumption and includes household hygiene practice effects, as previously suggested in India. ${ }^{1}$ Studies to identify the more likely causes for this contamination are needed to better produce, protect, and deliver safe drinking water.

In this study, the daily washing of the container used to store drinking water was a risk factor associated with a higher prevalence of carriers. The use of bleach and water to wash the container was associated with a lower prevalence of carriers. However, after adjusting for water source and daily washing, the use of bleach was no longer a significant factor but was still nonsignificantly linked to a lower risk of carriage. It is important to highlight that cleaning supplies for washing and daily washing were self-reported by mothers/caregivers and not evaluated by direct observation, which may have resulted in overreporting of container cleaning. Despite this potential bias, these results suggest that the use of biocidal agents, such as bleach, should be promoted as a part of good hygiene practices for washing containers and surfaces.

Boiling and chlorination are methods to make water safe to drink $^{7,29}$; however, a suboptimal practice may be ineffective in eliminating microorganisms. ${ }^{43,44}$ Water-hygiene practices are associated with the availability of treatment supplies and the mother's knowledge of water treatment and waterborne diseases. ${ }^{45,46}$ In this study, the reported frequencies of boiling and chlorine use were comparable with those described in another Peruvian community. ${ }^{44}$ We did not find an association between reported treatment practices and carrier status. This lack of association could be explained by ineffective water treatments or by social desirability bias of each household having to directly report to one of the study's field workers. The verification of treatment by direct observation, measurements of free chlorine, or a comparison of the bacterial load in untreated and treated water are actions that could help to clarify the association between boiling and chlorination and the prevalence of those who asymptomatically carry diarrheal pathogens.

Drinking water is not the only vehicle or source of enteric pathogens. Other potential sources of contamination in regards to children may be intra-domiciliary contacts, contaminated pacifiers, or glasses, and the direct ingestion of soil

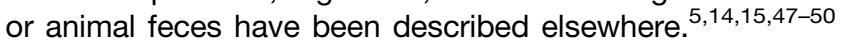
We evaluated samples from containers used to store the drinking water and not samples from domestic pipes or shared water sources. However, the high prevalence of children who tested positive for pathogens in households that used shared water sources should be considered as a warning signal that requires attention. It is challenging to elucidate correctly the association between water quality and pathogen carriage in this study because 1) both were measured in one point in time because of the cross-sectional design, 2) we did not confirm if children consumed the drinking water that was available at the study sampling day, and 3) covariates such as hygiene practices are susceptible to bias. In addition, our estimates do not account for the potential presence of geographic clustering within villages because we did not collect geolocation data from the study households, an issue that future studies can take into account. However, the drinking water was collected from the container that was usually used to store water consumed by the child and other people at home.

In conclusion, we found that the presence of very highrisk household drinking water was associated with a higher prevalence of children carrying pathogenic enteric bacteria. This association suggests that contaminated drinking water plays an important role in the generation of carriers and should be considered a threat to the health of the child and household. The promotion of good safety practices for handling and storing drinking water at home is needed to avoid exposures to risks. Further studies are needed to validate our results and better determine the risk of disease to the child and other household members. Evidencebased and appropriate public health measures to control infection with diarrheagenic pathogens are needed in rural communities of Peru. 
Received April 30, 2019. Accepted for publication February 11, 2020.

Published online March 23, 2020.

Acknowledgments: This article was prepared by S. L. in fulfillment of the requirements for a master's degree in Epidemiological Research offered by Universidad Peruana Cayetano Heredia (UPCH). We thank Jorge Izaguirre for his support in the coordination of the fieldwork. Also, we thank Dr. Andrea J. McCoy for her comments and critical review.

Financial support: Global Emerging Infections Surveillance (GEIS) and U.S. Naval Medical Research Unit No. 6 (NAMRU-6), Lima, Peru (Funding code: NMRCD.2009.0006). A. G. L. is sponsored by the training grant D43 TW007393 awarded by the Fogarty International Center of the U.S. National Institutes of Health awarded to Emerge, the Emerging Diseases and Climate Change Research Unit of the School and Public Health Administration at Universidad Peruana Cayetano Heredia.

Copyright statement: Several authors are employees of the U.S. government. This work was prepared as part of our official duties. Title 17 U.S.C. \$105 provides that copyright protection under this title is not available for any work of the U. S. Government. Title 17, U.S.C. §101 defines U.S. Government work as a work prepared by military service members or employees of the U.S. Government as part of that person's official duties.

Human use statement: The study protocol was approved by the Naval Medical Research Center Institutional Review Board (Protocol \# NMRCD.2009.0006) in compliance with all applicable Federal regulations governing the protection of human subjects.

Disclaimer: The views expressed in this article are those of the author and do not necessarily reflect the official policy or position of the Department of the Navy, Department of Defense, nor the U.S. Government.

Authors' addresses: Steev Loyola, School of Medicine, Universidad Peruana Cayetano Heredia, Lima, Peru, and U.S. Naval Medical Research Unit No. 6, Lima, Peru, E-mails: steev.loyola@gmail.com or steev.loyola@upch.pe. Juan F. Sanchez and Andres G. Lescano, U.S. Naval Medical Research Unit No. 6, Lima, Peru, and Emerge, Emerging Diseases and Climate Change Research Unit, School of Public Health and Administration, Universidad Peruana Cayetano Heredia, Lima, Peru, E-mails: chiroque@gmail.com or juan. sanchez209.In@mail.mil and willy.lescano@upch.pe. Edson Maguiña, Enrique Canal, Rosa Castillo, Manuela Bernal, Yocelinda Meza, Drake H. Tilley, and Claudio A. Rocha, U.S. Naval Medical Research Unit No. 6, Lima, Peru, E-mails: edson.a.maguina.ctr@mail.mil, enriquecanal@ hotmail.com or enrique.a.canal.In@mail.mil, rosa.m.castillo14.In@ mail.mil, manuela.m.bernal.In@mail.mil, yocelinda.a.meza.In@mail. mil or yocelindameza@gmail.com,dtilley@hotmail.com, and claudiorochacalderon@gmail.com. William E. Oswald, Faculty of Infectious and Tropical Diseases, London School of Hygiene \& Tropical Medicine, London, United Kingdom, E-mail: william.oswald@ Ishtm.ac.uk. Kristen Heitzinger, Asociacion Benefica PRISMA, Lima, Peru, E-mail: heitzk@uw.edu.

\section{REFERENCES}

1. Kundu A, Smith WA, Harvey D, Wuertz S, 2018. Drinking water safety: role of hand hygiene, sanitation facility, and water system in semi-urban areas of India. Am J Trop Med Hyg 99: 889-898.

2. Bain R, Cronk R, Wright J, Yang H, Slaymaker T, Bartram J, 2014. Fecal contamination of drinking-water in low- and middleincome countries: a systematic review and meta-analysis. PLoS Med 11: e1001644.

3. Pruss-Ustun A et al., 2014. Burden of disease from inadequate water, sanitation and hygiene in low- and middle-income settings: a retrospective analysis of data from 145 countries. Trop Med Int Health 19: 894-905.

4. Hutton G, Chase $C, 2016$. The knowledge base for achieving the sustainable development goal targets on water supply, sanitation and hygiene. Int J Environ Res Public Health 13: E536.
5. Luby SP, Halder AK, Huda TM, Unicomb L, Islam MS, Arnold BF, Johnston RB, 2015. Microbiological contamination of drinking water associated with subsequent child diarrhea. $A m \mathrm{~J}$ Trop Med Hyg 93: 904-911.

6. Darvesh N, Das JK, Vaivada T, Gaffey MF, Rasanathan K, Bhutta ZA; Social Determinants of Health Study Team, 2017. Water, sanitation and hygiene interventions for acute childhood diarrhea: a systematic review to provide estimates for the Lives Saved Tool. BMC Public Health 17 (Suppl 4): 776.

7. Cairncross S, Hunt C, Boisson S, Bostoen K, Curtis V, Fung IC, Schmidt WP, 2010. Water, sanitation and hygiene for the prevention of diarrhoea. Int J Epidemiol 39 (Suppl 1): i193-i205.

8. Healy-Profitos J, Lee S, Mouhaman A, Garabed R, Moritz M, Piperata B, Lee J, 2016. Neighborhood diversity of potentially pathogenic bacteria in drinking water from the city of Maroua, Cameroon. J Water Health 14: 559-570.

9. Pinto AJ, Schroeder J, Lunn M, Sloan W, Raskin L, 2014. Spatialtemporal survey and occupancy-abundance modeling to predict bacterial community dynamics in the drinking water microbiome. MBio 5: e0113514.

10. Katukiza AY, Ronteltap M, van der Steen P, Foppen JW, Lens PN, 2014. Quantification of microbial risks to human health caused by waterborne viruses and bacteria in an urban slum. $J$ Appl Microbiol 116: 447-463.

11. Swerdlow DL et al., 1992. Waterborne transmission of epidemic cholera in Trujillo, Peru: lessons for a continent at risk. Lancet 340: 28-33.

12. Gundry S, Wright J, Conroy R, 2004. A systematic review of the health outcomes related to household water quality in developing countries. J Water Health 2: 1-13.

13. Chakravarty I, Bhattacharya A, Das SK, 2017. Water, sanitation and hygiene: the unfinished agenda in the World Health Organization south-east Asia region. WHO South East Asia J Public Health 6: 22-33.

14. Gil Al, Lanata CF, Hartinger SM, Mäusezahl D, Padilla B, Ochoa TJ, Lozada M, Pineda I, Verastegui H, 2014. Fecal contamination of food, water, hands, and kitchen utensils at the household level in rural areas of Peru. J Environ Health 76: 102-106.

15. Hartinger SM, Lanata CF, Hattendorf J, Gil Al, Verastegui $H$, Ochoa T, Mausezahl D, 2011. A community randomised controlled trial evaluating a home-based environmental intervention package of improved stoves, solar water disinfection and kitchen sinks in rural Peru: rationale, trial design and baseline findings. Contemp Clin Trials 32: 864-873.

16. Miranda M, Aramburu A, Junco J, Campos M, 2010. State of the quality of drinking water in households in children under five years in Peru, 2007-2010. Rev Peru Med Exp Salud Publica 27: 506-511.

17. Oswald WE, Lescano AG, Bern C, Calderon MM, Cabrera L, Gilman $\mathrm{RH}, 2007$. Fecal contamination of drinking water within peri-urban households, Lima, Peru. Am J Trop Med Hyg 77: 699-704.

18. Burnham PM, Hendrixson DR, 2018. Campylobacter jejuni: collective components promoting a successful enteric lifestyle. Nat Rev Microbiol 16: 551-565.

19. Riveros M, Ochoa TJ, 2015. Relevant public health enteropathogens. Rev Peru Med Exp Salud Publica 32: 157-164.

20. Lee G, Paredes Olortegui M, Peñataro Yori P, Black RE, Caulfield L, Banda Chavez C, Hall E, Pan WK, Meza R, Kosek M, 2014. Effects of Shigella-, Campylobacter- and ETEC-associated diarrhea on childhood growth. Pediatr Infect Dis $J$ 33: 1004-1009.

21. Birgy A, Cohen R, Levy C, Bidet P, Courroux C, Benani M, Thollot $F$, Bingen E, 2012. Community faecal carriage of extendedspectrum beta-lactamase-producing Enterobacteriaceae in French children. BMC Infect Dis 12: 315.

22. Zhang $L$ et al., 2018. A gastroenteritis outbreak associated with drinking water in a college in northwest China. J Water Health 16: $508-515$

23. Coleman BL et al., 2012. The role of drinking water in the transmission of antimicrobial-resistant $E$. coli. Epidemiol Infect 140: 633-642.

24. Sorum H, L'Abee-Lund TM, 2002. Antibiotic resistance in foodrelated bacteria-a result of interfering with the global web of bacterial genetics. Int J Food Microbiol 78: 43-56. 
25. Revista Agua, 2007. Evaluación Rápida de Los Servicios de Agua y Saneamiento en el Area Afectada Por el Sismo: El Terremoto en Ica. Revista Agua.

26. EMAPISCO, 2011. Cobertura de Agua Potable y Alcantarillado. Available at: www.emapisco.com/servicios.php. Accessed June 2018.

27. ICF International, 2011. Demographic and Health Surveys Methodology-Questionnaires: Household, Woman's, and Man's. MEASURE DHS Phase III: Calverton, Maryland. Available at: http://www.measuredhs.com.

28. Guion CE, Ochoa TJ, Walker CM, Barletta F, Cleary TG, 2008. Detection of diarrheagenic Escherichia coli by use of meltingcurve analysis and real-time multiplex PCR. J Clin Microbiol 5: 1752-1757.

29. World Health Organization, 2011. Guidelines for Drinking-Water Quality, 4th edition. Geneva, Switzerland: WHO.

30. Gruber JS, Ercumen A, Colford JM, 2014. Coliform bacteria as indicators of diarrheal risk in household drinking water: systematic review and meta-analysis. PLoS One 9: e107429.

31. World Health Organization, 2006. WHO Child Growth Standards: Methods and Development. Geneva, Switzerland: WHO.

32. Vyas S, Kumaranayake L, 2006. Constructing socio-economic status indices: how to use principal components analysis. Health Policy Plan 21: 459-468.

33. Filmer D, Pritchett LH, 2001. Estimating wealth effects without expenditure data-or tears: an application to educational enrollments in states of India. Demography 38: 115-132.

34. Hayat MJ, Higgins M, 2014. Understanding poisson regression. J Nurs Educ 53: 207-215.

35. Barros AJ, Hirakata VN, 2003. Alternatives for logistic regression in cross-sectional studies: an empirical comparison of models that directly estimate the prevalence ratio. BMC Med Res Methodol 3: 21.

36. Wacholder S, 1986. Binomial regression in GLIM: estimating risk ratios and risk differences. Am J Epidemiol 123: 174-184.

37. Ferjani S, Saidani M, Hamzaoui Z, Alonso CA, Torres C, Maamar E, Slim AF, Boutiba BB, 2017. Community fecal carriage of broad-spectrum cephalosporin-resistant Escherichia coli in Tunisian children. Diagn Microbiol Infect Dis 87: 188-192.

38. Platts-Mills JA, Kosek M, 2014. Update on the burden of Campylobacter in developing countries. Curr Opin Infect Dis 27: 444-450.

39. Clasen T, Schmidt WP, Rabie T, Roberts I, Cairncross S, 2007. Interventions to improve water quality for preventing diarrhoea: systematic review and meta-analysis. BMJ 334: 782

40. Fewtrell L, Kaufmann RB, Kay D, Enanoria W, Haller L, Colford JM, 2005. Water, sanitation, and hygiene interventions to reduce diarrhoea in less developed countries: a systematic review and meta-analysis. Lancet Infect Dis 5: 42-52.

41. Heitzinger K, Rocha CA, Quick RE, Montano SM, Tilley DH, Mock CN, Carrasco AJ, Cabrera RM, Hawes SE, 2015. "Improved" but not necessarily safe: an assessment of fecal contamination of household drinking water in rural Peru. Am J Trop Med Hyg 93: 501-508.

42. Brown J, Hien VT, McMahan L, Jenkins MW, Thie L, Liang K, Printy E, Sobsey MD, 2013. Relative benefits of on-plot water supply over other 'improved' sources in rural Vietnam. Trop Med Int Health 18: 65-74.

43. Heitzinger K, Rocha CA, Quick RE, Montano SM, Tilley DH, Mock CN, Carrasco AJ, Cabrera RM, Hawes SE, 2016. The challenge of improving boiling: lessons learned from a randomized controlled trial of water pasteurization and safe storage in Peru. Epidemiol Infect 144: 2230-2240.

44. Rosa G, Huaylinos ML, Gil A, Lanata C, Clasen T, 2014. Assessing the consistency and microbiological effectiveness of household water treatment practices by urban and rural populations claiming to treat their water at home: a case study in Peru. PLoS One 9: e114997.

45. Rothstein JD, Leontsini E, Olortegui MP, Yori PP, Surkan PJ, Kosek M, 2015. Determinants of caregivers' use and adoption of household water chlorination: a qualitative study with periurban communities in the Peruvian Amazon. Am J Trop Med Hyg 93: 626-635.

46. Luby SP, Agboatwalla M, Painter J, Altaf A, Billhimer W, Keswick $B$, Hoekstra RM, 2006. Combining drinking water treatment and hand washing for diarrhoea prevention, a cluster randomised controlled trial. Trop Med Int Health 11: 479-489.

47. Oloruntoba EO, Folarin TB, Ayede AI, 2014. Hygiene and sanitation risk factors of diarrhoeal disease among under-five children in Ibadan, Nigeria. Afr Health Sci 14: 1001-1011.

48. Ngure FM et al., 2013. Formative research on hygiene behaviors and geophagy among infants and young children and implications of exposure to fecal bacteria. Am J Trop Med Hyg 89: 709-716.

49. Lietzau S, Raum E, von Baum H, Marre R, Brenner H, 2007. Household contacts were key factor for children's colonization with resistant Escherichia coli in community setting. J Clin Epidemiol 60: 1149-1155.

50. Exum NG, Kosek MN, Davis MF, Schwab KJ, 2017. Surface sampling collection and culture methods for Escherichia coli in household environments with high fecal contamination. Int $J$ Environ Res Public Health 14: E947. 